\title{
SISTEM INFORMASI GEOGRAFIS SEBAGAI MEDIA INFORMASI PAJAK BUMI DAN BANGUNAN (PBB) DI KOTA KAYU AGUNG
}

\author{
Jaka Purnama ${ }^{1}$, Darius Antoni ${ }^{2}$, Muhamad Akbar ${ }^{3}$ \\ Program Pascasarjana \\ ${ }_{1,2,3}$ Universitas Bina Darma \\ 1,2,3jakapurnama33@gmail.com,darius.antoni@binadarma.ac.id, muhamad.akbar@binadarma.ac.id \\ Jl. A. Yani No. 12, Palembang 30624, Indonesia
}

\begin{abstract}
Abstrak
Penelitian ini adalah untuk meyediakan sebuah media untuk palayanan informasi tentang Pajak Bumi dan Bangunan Daerah di Kota Kayu Agung. Dengan menggunakan ISO 9126. Dalam pengembangan sistem penelitian ini menggunakan metode RAD dan penggambaran sistem menggunakan Diagram Konteks, DAD Level 0, dan ERD. Dalam membangun aplikasi ini menggunakan bahasa pemrograman web(HTML,CSS,PHP, dan Javascript) lalu menggunakan basisdata MySQL MariaDB. Dan hasilnya berupa sebuah web service media pelayanan informasi Pajak Bumi dan Bangunan yaitu Service Informasi Alokasi Pada Pajak Bumi dan Bangunan (SIAP PBB) di Kota Kayu Agung.
\end{abstract}

Kata Kunci : SIG PBB, Pelayanan Informasi PBB, RAD, ISO 9126

\begin{abstract}
This study is to provide a media to improve service information about the Land and Regional Building Tax in Kayu Agung City. Based On ISO 9126. In developing the system this research uses the RAD method and depicts the system using Context Diagram, DAD Level O, and ERD. In building this application using the web programming language (HTML, CSS, PHP, and JavaScript) then using the MariaDB MySQL database. And the results are in the form of a web service service for land and building tax information, namely information service allocation for land and building tax (SIAP PBB) in Kayu Agung City.
\end{abstract}

Keywords: GIS PBB, Information System Tax, RAD, ISO 9126

\section{PENDAHULUAN}

Pajak Bumi dan Bangunan (PBB) adalah pajak Negara yang dikenakan terhadap Bumi dan Bangunan. Berdasarkan Undang-Undang No. 12 Tahun 1985 Tentang Pajak Bumi dan Bangunan sebagaimana diubah dengan Undang-undang No.12 Tahun 1994 Pasal 1 Ayat 2 dijelaskan bahwa Pajak Bumi dan Bangunan adalah pajak negara yang sebagian besar penerimaannya merupakan pedapatan daerah yang antara lain dipergunakan untuk penyediaan fasilitas yang juga dinikmati oleh Pemerintah Pusat dan Pemerintah Daerah. Pajak Bumi dan Bangunan terutang ditetapkan oleh keadaan objek yaitu bumi atau tanah dan bangunan sedangkan keadaan subjek (siapa yang membayar) tidak ikut menentukan besarnya pajak terutang (Sidharta \& Wati 2015). PBB adalah iuran yang dikenakan terhadap pemilik, pemegang kekuasaan, penyewa dan yang memperoleh manfaat dari bumi dan bangunan. Pengertian bumi adalah permukaan bumi dan tubuh bumi yang ada dibawahnya. Bumi menunjuk pada permukaan bumi meliputi tanah dan perairan pedalaman serta laut wilayah Indonesia. Bangunan adalah konstruksi teknik yang ditanam atau diletakan secara tetap pada tanah dan perairan 
dengan digunakan sebagai tempat tinggal atau tempat berusaha (Saputro 2014). Pajak Bumi dan Bangunan adalah pajak yang bersifat kebendaan dalam arti besarnya pajak terutang ditentukan oleh keadaan objek yaitu bumi/tanah dan atau bangunan (Adelina 2013).

Pajak Daerah Kayu Agung yang dikelola Badan Pengelola Pajak Daerah (BPPD) Kabupaten Ogan Komering Ilir (OKI) tahun 2017, realisasinya tidak mencapai target yang telah ditetapkan. Berdasarkan LKJIP (Laporan Kinerja Instansi Pemerintah) tabel Indikator Persentase Kenaikan Pendapatan Asli Daerah tahun 2017 terealisasi sebesar 95\% dari target 100\% dengan capaian sebesar 95\% sehingga untuk ketersediaan realisasi pendapatan asli daerah sudah terpenuhi. Apabila dibandingkan dengan realisasi pendapatan asli daerah tahun 2016 sebesar 100\% dengan capaian sebesar 93,93\%, sedangkan dibandingkan dengan target RPJMD tahun 2018 sebesar 100\% maka diperoleh realisasi sebesar 95\%, dengan adanya data seperti ini perlu upaya dan kinerja maksimal dari dinas terkait, agar kedepan realisasi penerimaan pajak daerah ini bisa melampaui target serta bisa menggali potensi-potensi lain yang belum memberikan kontribusinya bagi Pendapatan Asli Daerah (PAD) Kabupaten OKI. Walaupun angka realisasi terbilang cukup besar, informasi tentang asal pendapat belum di jelaskan secara rinci termasuk informasi tentang PBB. Informasi LKJIP tersebut bisa di dapatkan melalui website Kabupaten OKI, namun masih banyak masyarakat yang belum mengetahui hal tersebut karena informasi tersebut tidak diumumkan secara resmi dan terbuka di website resmi Kabupaten OKI. Jika pun masyarakat ingin mendapatkan informasi PBB baik itu tagihan maupun informasi tentang PBB lainnya, mereka harus bertanya kepada ketua RT atau RW setempat, pegawai kelurahan atau kecamatan bahkan masyarakat harus bersusah payah datang ke kantor pajak dan kemudian bertanya kepada pegawai setempat agar informasi tersebut bisa didapatkan. Selain membuat masyarakat menghabiskan waktu dan biaya, pekerjaan pegawai pemerintahan pun akan terhambat dikarenakan harus menyiapkan informasi yang masyarakat butuhkan. Hal tersebut membuat teknologi informasi masih kurang tepat penggunaanya mengingat teknologi informasi dibuat untuk mempermudah pekerjaan dalam pemerintahan, sehingga teknologi yang ada menjadi tidak efesien dan mengakibatkan informasi khususnya informasi PBB susah untuk didapatkan. Oleh karena itu kebutuhan masyarakat untuk mencari dan memperoleh informasi seputar PBB menjadi tidak terpenuhi. Maka dari itu dibutuhkan suatu media agar informasi yang masyarakat butuhkan tentang PBB tersempaikan dengan baik, karena dalam BookletPBB Hak wajib pajak adalah mendapatkan penjelasan berkaitan dengan ketetapan PBB dalam hal Wajib Pajak Meminta.

Salah satu instansi pemerintahan yang mengurus teknologi informasi dalam upaya meningkatkan kinerja pelayanan mereka adalah Dinas KOMINFO (Komunikasi dan Informatika) Kabupaten OKI (Ogan Komering Ilir). Salah satu Visi KOMINFO adalah pembangunan KOMINFO yang merakyat, yang maksudnya adalah ketepatan sasaran pembangunan KOMINFO kepada masyarakat pengguna dan keterjangkauan masyarakat untuk mendapatkan, memanfaatkan, mengolah dan mengakses informasi, sehingga mempercepat pertumbuhan ekonomi sekaligus mewujudkan dan meningkatkan daya saing bangsa (KOMINFO, 2010).

Sehingga penelitian ini difokuskan untuk membuat aplikasi dengan konsep web service berbasis GIS dan mobile yang dapat membantu Dinas KOMINFO dalam menyediakan media sebagai wadah agar masyarakat dapat mendapatkan informasi tentang PBB. Karena pada visi KOMINFO mereka harus menyediakan informasi sehingga masyarakat mendapatkan maanfaat untuk mempercepat pertumbuhan ekonomi. Maka dari itu, penelitian ini akan membuat sebuah aplikasi berupa web service dengan nama "Sistem Informasi Geografis Sebagai Media Informasi Pajak Bumi dan Bangunan (PBB) di Kota Kayu Agung" yang akan menampilkan informasi terkait PBB di kota kayu agung.

\section{METODOLOGI PENELITIAN}

Seorang peneliti sebelum melakukan penelitian mereka akan melakukan pendekatan yang dianggap paling cocok, yaitu sesuai dengan masalah yang akan dipecahkan (pertimbangan efektivitas). Kemudian pertimbangan lainnya adalah terletak pada masalah efisiensi, yaitu dengan mempertimbangkan keterbatasan dana, tenaga, waktu dan kemampuan dari peneliti.

Metode penelitian yang digunakan dalam penelitian ini adalah bersifat deskriptif. Menurut Nazir (2005), Metode deskriptif merupakan suatu metode untuk meneliti status kelompok manusia, suatu objek, suatu kondisi, suatu sistem pemikiran, ataupun suatu kelas peristiwa pada masa sekarang. 


\subsection{Konsep Model Penelitian}

Berdasarkan teori yang mendukung, maka dapat dirumuskan suatu kerangka teori yaitu sistem informasi terkait PBB berupa Sistem Informasi Geografis sebagai media informasi pajak bumi dan bangunan (pbb).

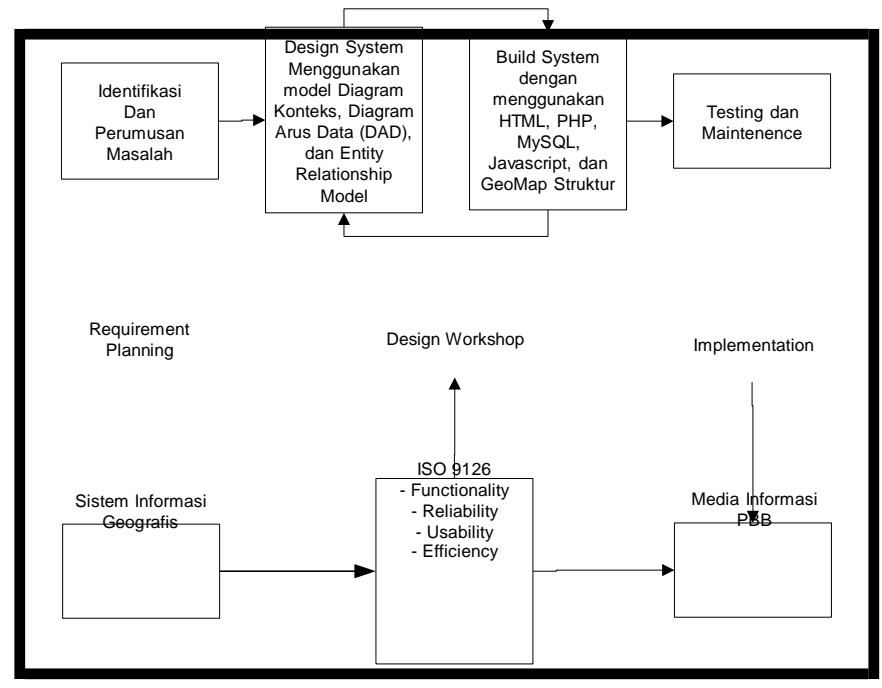

Gambar 1. Kerangka Teori Berdasarkan RAD

Sistem informasi geografis yang akan di buat sebagai media informasi akan menggunakan iso 9126 sebagai pedoman pengembangan sehingga pada saat design sistem akan mengikuti indikator yang ada pada iso 9126 . Kemudian setelah sistem berhasil dibuat sistem tersebut akan menjadi sebuah media informasi pbb yang memiliki iso 9126 di dalamnya.

\subsection{Tinjauan Pustaka}

Kualitas perangkat lunak dapat dinilai melalui ukuran-ukuran dan metode-metode tertentu, serta melalui pengujian-pengujian software. Salah satu tolak ukur kualitas perangkat lunak adalah ISO 9126, yang dibuat oleh International Organization for Standardization (ISO) dan International Electrotechnical Commission (IEC). ISO 9126 mendefinisikan kualitas produk perangkat lunak, model, karakteristik mutu, dan metrik terkait yang digunakan untuk mengevaluasi dan menetapkan kualitas sebuah produk software. Standar ISO 9126 telah dikembangkan dalam usaha untuk mengidentifikasi atribut-atribut kunci kualitas untuk perangkat lunak komputer. Faktor kualitas bertujuan memberikan gambaran atau mendeskripsikan masing-masing variabel yang diteliti dan menggali keterkaitan masing-masing variabel. Pengujian manfaat yang digunakan yaitu functionality, reliablity, usability dan efficiency sebagai evaluasi perangkat lunak. Atribut uji manfaat yang digunakan berdasarkan ISO 9126 yang mengidentifikasi empat karakteristik kualitas dari Sistem Informasi Geografis sebagai berikut:

1. Functionality (Fungsionalitas). Kemampuan perangkat lunak untuk menyediakan fungsi sesuai kebutuhan pengguna, ketika digunakan dalam kondisi tertentu.

2. Reliability (Kehandalan). Kemampuan perangkat lunak untuk mempertahankan tingkat kinerja tertentu, ketika digunakan dalam kondisi tertentu.

3. Usability (Kebergunaan). Kemampuan perangkat lunak untuk dipahami, dipelajari, digunakan, dan menarik bagi pengguna, ketika digunakan dalam kondisi tertentu.

4. Efficiency (Efisiensi). Kemampuan perangkat lunak untuk memberikan kinerja yang sesuai dan relatif terhadap jumlah sumber daya yang digunakan pada saat keadaan tersebut.

\section{Tabel 2.1 Atribut Functionality}

\begin{tabular}{ll}
\hline \multicolumn{1}{c}{ Sub-Karakteristik } & \multicolumn{1}{c}{ Deskripsi } \\
\hline Suitability & Kemampuan perangkat lunak untuk menyediakan serangkaian fungsi yang \\
& sesuai untuk tugas-tugas tertentu dan tujuan pengguna. \\
Accuracy & Kemampuan perangkat lunak dalam memberikan hasil yang presisi dan benar \\
& sesuai dengan kebutuhan. \\
Security & Kemampuan perangkat lunak untuk mencegah akses yang tidak diinginkan, \\
menghadapi penyusup (hacker) maupun otorisasi dalam modifikasi data. & Kemampuan perangkat lunak untuk berinteraksi dengan satu atau lebih sistem \\
\hline
\end{tabular}




\begin{tabular}{cl}
\hline \multicolumn{1}{c}{ Sub-Karakteristik } & \multicolumn{1}{c}{ Deskripsi } \\
\hline & tertentu. \\
Compliance & Kemampuan perangkat lunak dalam memenuhi standar dan kebutuhan sesuai \\
& peraturan yang berlaku.
\end{tabular}

Sumber: ISO/IEC FDIS 9126-1:2000

Tabel 2.2 Atribut Reliability

\begin{tabular}{ll}
\hline \multicolumn{1}{c}{ Sub-Karakteristik } & \multicolumn{1}{c}{ Deskripsi } \\
\hline Maturity & $\begin{array}{l}\text { Kemampuan perangkat lunak untuk menghindari kegagalan sebagai akibat dari } \\
\text { kesalahan dalam perangkat lunak. }\end{array}$ \\
Fault tolerance & $\begin{array}{l}\text { Kemampuan perangkat lunak untuk mempertahankan kinerjanya jika terjadi } \\
\text { kesalahan perangkat lunak. } \\
\text { Kemampuan perangkat lunak untuk membangun kembali tingkat kinerja ketika } \\
\text { Recoverability }\end{array}$ \\
\hline terjadi kegagalan sistem, termasuk data dan koneksi jaringan.
\end{tabular}

Sumber: ISO/IEC FDIS 9126-1:2000

Tabel 2.3 Atribut Usability

\begin{tabular}{ll}
\hline \multicolumn{1}{c}{ Sub-Karakteristik } & \multicolumn{1}{c}{ Deskripsi } \\
\hline Understandibility & Kemampuan perangkat lunak dalam kemudahan untuk dipahami. \\
Learnability & Kemampuan perangkat lunak dalam kemudahan untuk dipelajari. \\
Operability & Kemampuan perangkat lunak dalam kemudahan untuk dioperasikan. \\
Attractiveness & Kemampuan perangkat lunak dalam menarik pengguna. \\
\hline
\end{tabular}

Sumber: ISO/IEC FDIS 9126-1:2000

\section{Tabel 2.4 Atribut Efficiency}

\begin{tabular}{ll}
\hline Sub-Karakteristik & Deskripsi \\
\hline Time behavior & Kemampuan perangkat lunak dalam memberikan respon dan waktu pengolahan \\
& yang sesuai saat melakukan fungsinya. \\
Resource behavior & $\begin{array}{l}\text { Kemampuan perangkat lunak dalam menggunakan sumber daya yang } \\
\text { dimilikinya ketika melakukan fungsi yang ditentukan. }\end{array}$ \\
\hline
\end{tabular}

Sumber: ISO/IEC FDIS 9126-1:2000

\section{HASIL DAN PEMBAHASAN}

Tujuan pengembangan sistem (system development) adalah menyusun suatu sistem yang baru untuk menggantikan sistem yang lama secara keseluruhan atau memperbaiki sistem yang telah ada. Faktor-faktor yang mendorong pengembangan sistem yaitu adanya problems, opportunities dan directives (Bentley, Dittman, \& Whitten, 2000).

a. Masalah, peluang dan Arahan

Masalah-masalah yang ditangani :

1. Kesulitan dalam menemukan informasi lokasi terkait pbb.

2. Kesulitan dalam mencari informasi terkait pembayaran pbb.

3. Kesulitan dalam mencari berita tentang pbb.

4. Kesulitan dalam dalam mencari informasi di berbagai perangkat.

5. Kesulitan dalam mencari informasi dengan harus mendatangi tempat pbb atau informan terdekat.

Peluang dapat dilihat dari keinginan para petugas yang terkait dengan SIAP PBB untuk mengembangkan sistem informasi ini. Dan keinginan untuk meningkatkan mutu pelayanan Dinas Setempat dengan mengoptimalkan fungsi komputer sebagai pengolah data, karena selama ini belum ada media untuk pelayanan informasi tersebut.

Arahan dilihat dari hasil observasi dengan pihak yang berhubungan langsung dengan sistem yang akan dikembangkan, dalam hal ini direktur Dinas DISPENDA dan Dinas KOMINFO.

Berdasarkan alur proses penyediaan informasi, maka merancang SIAP PBB untuk mendukung penyediaan informasi terkait PBB diperlukan langkah-langkah sistematis dengan metodologi RAD. Metode ini digunakan karena mendasari semua metode pengembangan sistem yaitu : melibatkan para pengguna sistem dan menggunakan pendekatan pemecahan masalah, membentuk fase dan aktivitas dalam mengelola proses dan proyek, mendesain sistem yang sesuai dengan perubahan dan perkembangan teknologi (McConnell 1996). Hasil penelitian berdasarkan metodologi RAD adalah sebagai berikut : 


\subsection{Tahap Rencana Kebutuhan (Requirement Planning)}

Untuk menghasilkan sistem informasi tersebut maka dapat dijabarkan beberapa rencana kebutuhan yaitu :

1. Kebutuhan Hardware

a. Server dengan minimal processor Intel Dual Core $1.66 \mathrm{GHz}$

b. Memory 2 GB dan 128GB SSD.

c. Layar Resolusi $1366 \times 768$.

d. Jaringan Internet yang terkoneksi ke Server

2. Kebutuhan Software

a. Sistem Operasi windows 7 atau terbaru.

b. XAMPP Versi 7.X.X.

c. Browser Google Chrome Versi Terbaru.

d. Web Editor dan File Transfer Protocol (FTP) Aplication

3. Kebutuhan Input

Elemen utama dalam membentuk sebuah sistem terdiri dari input, proses, dan output (Kadir 1999). Input yang membentuk suatu sistem informasi bisa berupa jenis sumber daya yang ada pada sistem informasi saat ini, yaitu : pengguna sistem dan sumber data yang dibutuhkan dalam SIAP PBB.

Pengguna sistem yang terlibat langsung dalam pengelolaan data dan informasi PBB adalah Dinas DISPENDA(Dinas Pendapatan Daerah), Petugas Kominfo, dan Pembayar PBB. Sumber data untuk SIAP PBB berasal dari database pembayar pajak DISPENDA. Sumber data yang dibutuhkan dalam SIAP PBB yaitu :
a. Data Berita
b. Data Pembayar Pajak PBB
c. Data Koordinat PBB
d. Data Wewenang SIAP PBB
e. Data Pembayaran PBB

4. Kebutuhan Informasi

Elemen sistem selanjutnya merupakan proses yang terjadi dalam SIAP PBB, yaitu kegiatan pengelolaan data. Pengelolaan dilakukan dengan mengolah sumber data yang ada menjadi informasi berupa :
a. Informasi Berita PBB
b. Informasi Koordinat PBB
c. Informasi Total Pembayar PBB
d. Informasi Pemegang Wewenang
e. Informasi Pembayar PBB
f. Informasi Pembayaran PBB

5. Kebutuhan Output

Output merupakan salah satu elemen sistem setelah dilakukan kegiatan pemrosesan data yang menghasilkan keluaran berupa informasi atau laporan yang dibutuhkan pada SIAP PBB.

Berdasarkan hasil wawancara, kebutuhan output dapat berupa informasi untuk mendukung penyampaian pelayanan, yaitu:

Tabel 3.1 Kebutuhan Informasi Berdasarkan Pengguna

\begin{tabular}{cll}
\hline Nomor & \multicolumn{1}{c}{ Pengguna } & \multicolumn{1}{c}{ Kebutuhan Informasi } \\
\hline 1 & Dinas Kominfo & - Informasi Berita PBB \\
& & - Informasi Koordinat PBB \\
& & - Informasi Pembayar PBB \\
& & -Informasi Total Pembayar PBB \\
& & - Informasi Pembayaran PBB \\
& & - Informasi Pemegang Wewenang \\
2 & Dinas DISPENDA & - Informasi Koordinat PBB \\
3 & & - Informasi Berita PBB \\
& Pembayar PBB & - Informasi Koordinat PBB \\
& & - Informasi Pembayar PBB \\
& & - Informasi Total Pembayar PBB \\
& & - Informasi Pembayaran PBB \\
\hline
\end{tabular}


Kebutuhan user dengan dibangunnya SIAP PBB untuk mendukung pelayanan PBB adalah dapat menghasilkan informasi yang bermanfaat sebagai penyedia informasi tentang PBB yang diperuntukan untuk masyarakat atau pembayar PBB. Namun karena sistem yang saat ini belum menyediakan pelayanan informasi tersebut maka informasi yang dihasilkan tidak lengkap, tidak akurat, tidak sesuai dengan kebutuhan untuk memenuhi kebutuhan informasi pembayar PBB. Dengan adanya SIAP PBB dapat memenuhi bahwa semua sistem informasi memiliki kegiatan utama yaitu menerima data sebagai masukan (input), kemudian memprosesnya dengan melakukan penghitungan, penggabungan unsur data, pemutakhiran akun dan memperoleh informasi sebagai keluaran (output) (Pohan \& Bahri 1997).

6. Kebutuhan Antar Muka

User interface (antar muka) untuk mengoperasikan sistem informasi service alokasi pajak bumi dan bangunan yaitu keyboard, mouse. Secara fisik, antarmuka pemakai yang dirancang adalah tampilan layar menu pilihan untuk wewenang (pusat,admin dan editor), form isian dan laporan terkait dengan data yang diolah.

\subsection{Tahap Desain Sistem}

Tahap desain dapat dilihat dengan desain arsitektur penggunaan aplikasi. Serta dapat juga dilihat dalam perancangan antar muka seperti pada gambar di bawah ini.

1) Diagram Konteks

Diagram konteks merupakan diagram paling atas dari sistem informasi yang menggambarkan aliran-aliran data ke dalam dan keluar entitas-entitas eksternal. Proses-proses dan aliran data yang terjadi dalam sistem SIAP PBB ini digambarkan secara logik dalam bentuk diagram alir data (DAD) menggunakan metodologi dan simbol-simbol yang disusun oleh De Marco-Yourdan.

Perangkat lunak Bantu (case tools) pengembangan sistem yang digunakan untuk menggambarkan proses-proses ini adalah Microsoft Visio 2007.

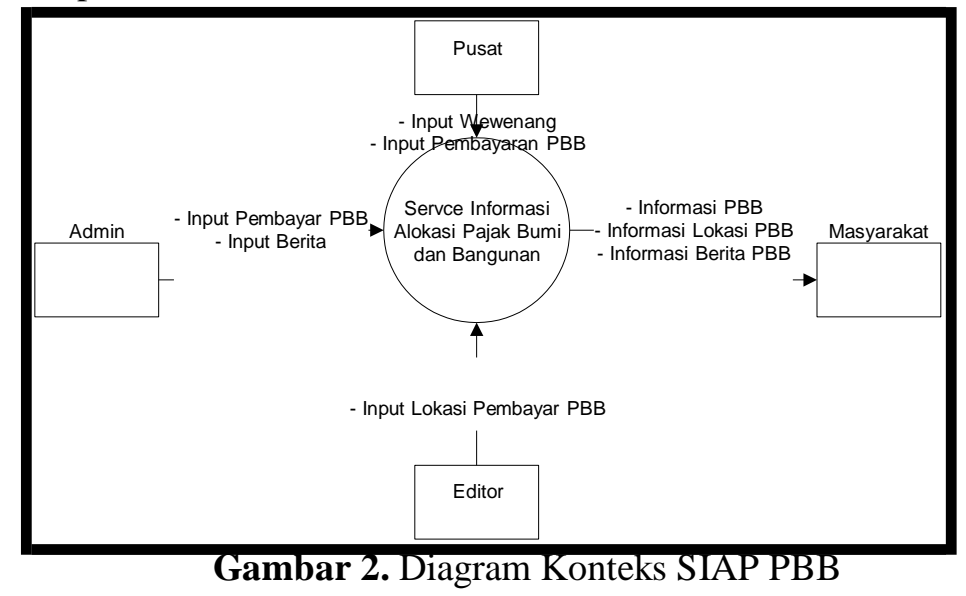

Pada diagram kontek terdapat empat entitas yang memiliki proses tersendiri :

a. Pusat, Level pusat dipegang oleh Dinas KOMINFO sebagai penyedia media layanan level pusat memiliki akses untuk menambah wewenang dan input data pembayar PBB

b. Admin, Level admin dipegang oleh Dinas DISPENDA sebagai penyedia informasi yang memiliki akses untuk menambah berita dan generate pembayaran PBB

c. Editor, Level Editor dipegang oleh Dinas KOMINFO maupun Dinas DISPENDA yang level aksesnya hanya sebagai editor koordinat pembayar PBB.

d. Masyarakat, Penerima informasi terkait PBB yang mendapatkan semua informasi dari aplikasi SIAP PBB.

Diagram konteks yang baru sesuai dengan teori yang menyatakan bahwa diagram konteks merupakan aliran data dan hanya memuat satu proses, menunjukkan sistem secara keseluruhan, semua entitas eksternal ditunjukkan pada diagram konteks berikut aliran data utama menuju ke sistem dan berasal dari sistem. Selain itu fungsi diagram konteks pada sistem yang dirancang bisa memetakan 
model lingkungan yang direpresentasikan dalam lingkaran tunggal yang mewakili keseluruhan sistem meliputi : kelompok pemakai, data masuk, data keluar, penyimpanan data serta batasan antara sistem dengan lingkungan (Bentley, Dittman et al. 2000).

2) Diagram Alir Data (DAD)

Setelah diagram konteks digambarkan maka diagram konteks akan diturunkan dalam bentuk yang lebih rinci, dengan mendefinisikan proses apa saja yang terdapat dalam sistem yaitu DAD level 0 . DAD fisik level 0 merupakan perluasan dari diagram konteks, sehingga hanya menggambarkan antarmuka antar organisasi atau unit (Bentley, Dittman et al. 2000).

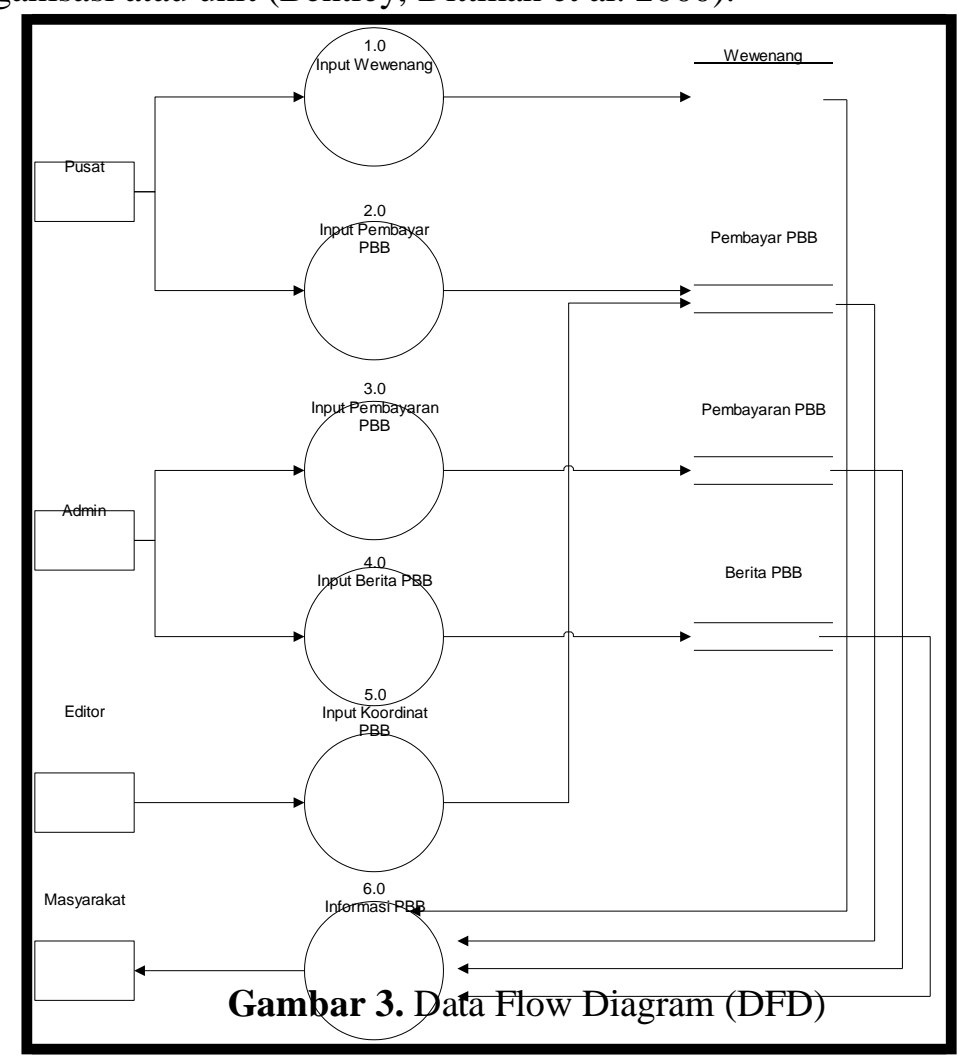

Terdapat 6 Proses dalam sistem SIAP PBB :

1. Proses Wewenang, Pada Proses ini Level Pusat dapat menambahkan hak akses untuk dapat masuk ke dalam aplikasi SIAP PBB

2. Input Pembayar PBB, Pada proses ini level pusat akan melakukan pengambilan data pembayar pajak yang ada pada sistem pajak.

3. Input Pembayaran PBB, Pada proses ini level admin akan melakukan pengambilan data pembayaran pajak yang ada pada sistem pajak.

4. Input Berita PBB, Pada proses ini level admin akan melakukan penambahan berita terkait dengan informasi PBB.

5. Input Koordinat PBB, Pada proses ini level pusat, admin, dan editor akan melakukan penambahan koordinat wilayah $\mathrm{PBB}$.

6. Informasi PBB, Pada proses ini masyarakat atau pembayar PBB dapat menerima informasi dari aplikasi SIAP PBB.

3. Pendekatan Model Data E-R (Entity-Relationship)

Perancangan basis data bertujuan untuk memudahkan atau efisiensi dalam penyimpanan, perubahan, dan pembacaan data. Suatu basis data yang dibangun seharusnya bisa reliable dengan peyimpanan data yang mempunyai integrasi tinggi untuk meningkatkan kepercayaan dari pengguna 
data, serta bisa diadaptasi dan ditingkatkan untuk suatu permintaan atau aplikasi yang baru dan tidak terduga. Untuk merancang basis data, analis perlu mendefinisikan terlebih dahulu field yang diperlukan oleh sistem (Bentley, Dittman et al. 2000).

Tabel 3.2 Primary Key setiap Entitas

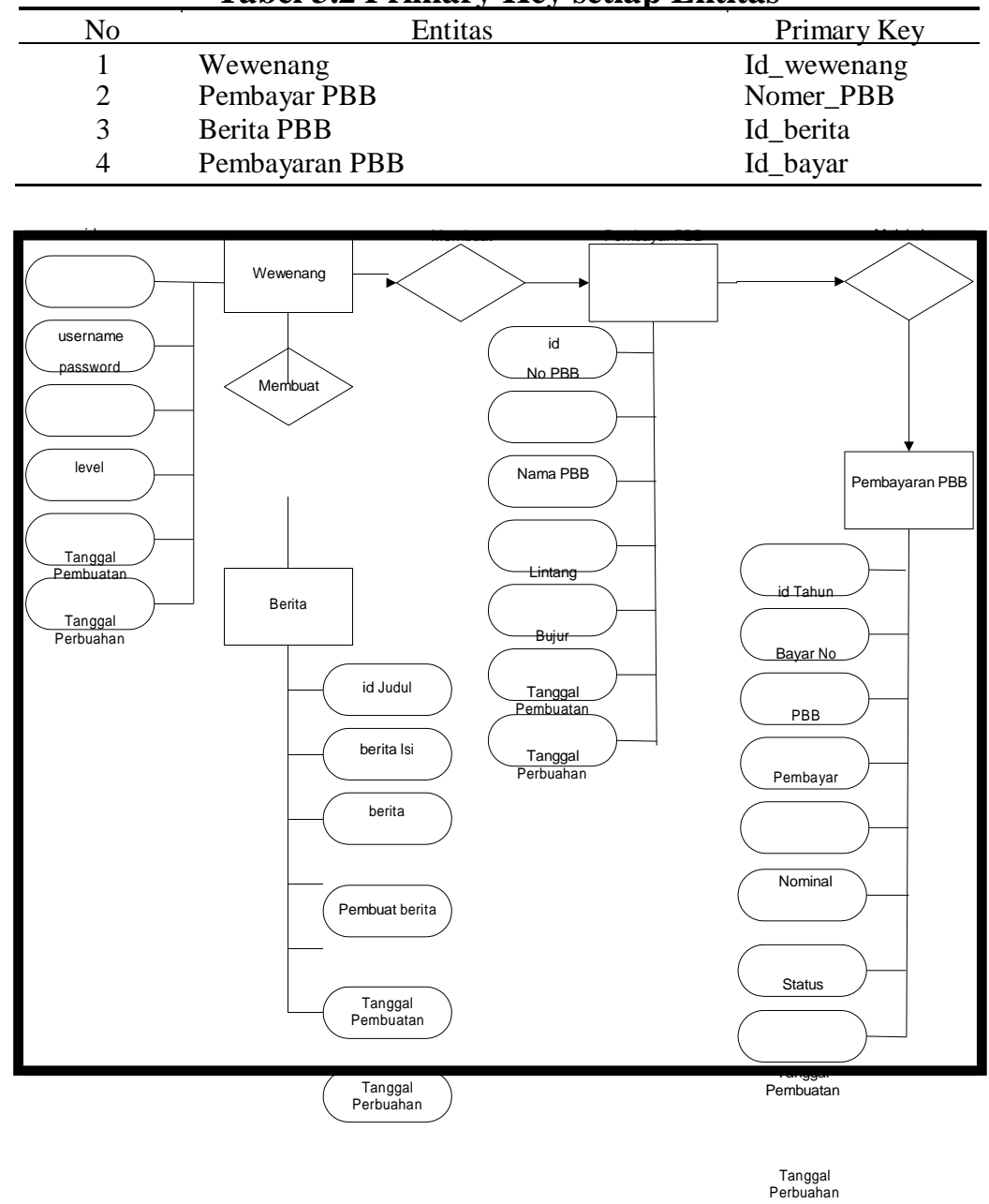

Gambar 4. Entity Relationship Diagram

Mengidentifikasi dan menetapkan seluruh himpunan relasi diantara himpunan entitas yang ada, serta menentukan derajat/ kardinalitas relasi untuk setiap himpunan relasi. Relasi-relasi yang terjadi antar entitas antara lain :

1. Relasi Antara Wewenang dan Berita, Wewenang yang memiliki akses level admin dapat membuat berita sesuai dengan informasi yang ada terkait PBB. Pemegang wewenang dapat membuat banyak berita atau artikel sehingga kardinalitasnya adalah many to many.

2. Relasi Wewenang dan Pembayar PBB, Wewenang yang memiliki akses level pusat dapat menambahkan pembayar pbb sesuai dengan data yang ada pada data pembayar pbb. Pemegang wewenang dapat menambahkan banyak data pembayar pbb sesuai dengan data yang ada pada Dinas DISPENDA sehingga kardinaliasnya adalah many to many.

3. Relasi Pembayar PBB dan Pembayaran PBB, Pembayar PBB dapat mendapatkan tagihan pembayaran PBB setiap tahun dan dapat melakukan satu kali pembayaran setiap tahunnya sehingga kardinalitasnya ada one to many.

\subsection{Tahap Implementasi}

Tujuan dari tahap ini adalah membangun (pemrograman) dan menguji sistem sesuai kebutuhan dan spesifikasi rancangan, mengimplementasikan interface aplikasi yang akan dibbuat. Uraian dari tiap tujuan dijelaskan sebagai berikut :

a. Pemrograman 
Tahap ini bertujuan untuk mengkonversikan hasil perancangan logika ke dalam kegiatan operasi pengkodean dengan menggunakan bahasa pemrograman sehingga konsep logikal yang sudah dirancang dapat diterjemahkan ke dalam fungsi-fungsi program yang dapat digunakan pemakai dengan mudah dan memastikan bahwa semua fungsi atau modul program dapat dibuat dan dapat berjalan secara benar (Bentley, Dittman et al. 2000). Pada penelitian ini mengingat keterbatasan waktu program sistem informasi rekam medis rawat jalan untuk mendukung evaluasi pelayanan dikerjakan peneliti dibantu oleh seorang programmer. Adapun program dibuat berdasar perancangan meliputi :

1) Pembuatan Basis Data

Pada perancangan basis data dimulai dari perancangan model menggunakan diagram konteks dan DAD, kemudian dimodelkan dengan ERD sehingga didapatkan tabel-tabel. Tabel basis data dibuat dengan tools database MysSQL type MariaDB version 10.1.37, Mengguanakan MySQL dengan tujuan untuk membuat aplikasi ini dapat di onlinekan sehingga memenuhi kebutuhan dalam pemecahan permasalahan.

2) Pembuatan Form dan Tampilan data

Pada proses ini penulis menggunakan Bahasa pemrograman HTML versi 5, framework bootsrap CCS versi 4 dan Javascript Versi 1 sehingga tampilan lebih menarik dan mudah dimengerti oleh EndUser.

3) Proses pengolahan data

Pada proses pengolahan data penulis mengguankan bahasa pemograman PHP Native versi 7 dan bahasa JSON yang dapat membantu dalam menampilkan data koordinat.

Setelah tahap pengkodean selesai dilakukan, selanjutnya adalah tahap pengujian yang bertujuan melakukan pengujian atau pengetesan terhadap semua modul program yang dibuat, sehingga pada saat diimplementasikan nanti dipastikan berjalan dengan baik dan tidak menimbulkan pemborosan sumberdaya yang digunakan. Kadir (2003) menjelaskan dalam melakukan pengujian program akan menggunakan urutan sebagai berikut :

1) Pengetesan dasar, yaitu melakukan pengujian di bagian modul yang paling kecil, sehingga dipastikan bagian tersebut berjalan dengan benar dan efisien.

2) Pengetesan kelompok, yaitu melakukan tes untuk kelompok-kelompok dasar modul sehingga interaksi antar modul dapat berjalan dengan baik.

3) Pengetesan fungsi, yaitu melakukan tes untuk pengujian pada fungsi-fungsi grup sehingga interaksi antar grup dapat berjalan dengan baik.

4) Pengetesan sistem, yaitu melakukan pengujian sistem secara keseluruhan, sehingga sistem dapat bekerja sesuai dengan harapan dan fungsi sebenarnya.

Dalam tahapan ini dapat dilihat dengan melakukan pengujian sistem informasi yang dibuat. Pengujian sistem dapat ditunjukkan dengan gambar hasil dari sistem seperti di bawah ini.

Halaman data pembayar PBB adalah halaman berisikan tentang biodata dan informasi tentang si pembayar PBB informasi yang ditampilkan sesuai dengan privasi dan arahan dari Dinas DISPENDA sehingga data pembayar PBB masih dapat dijaga kerahasiannya.

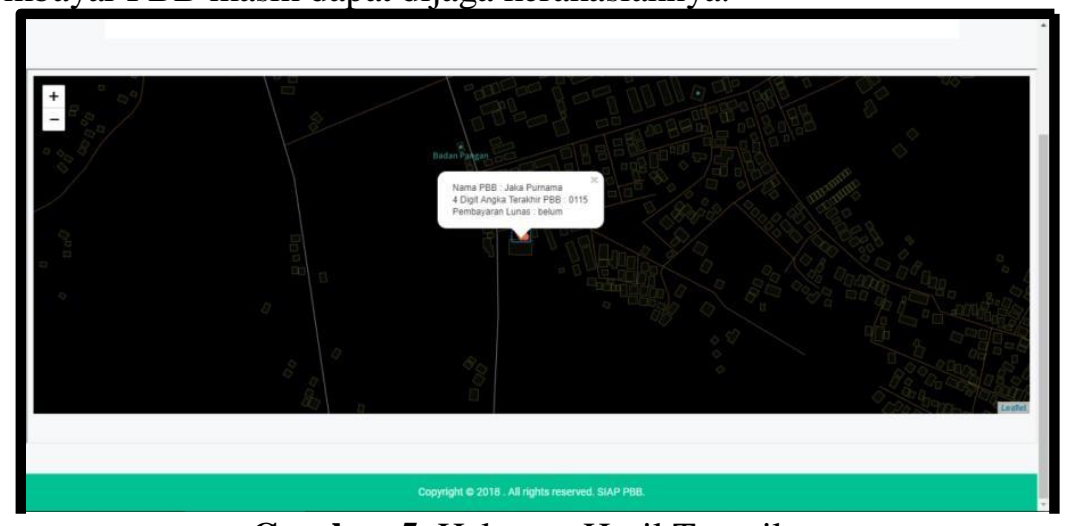

Gambar 5. Halaman Hasil Tampilan

Halaman hasil tampilan dari inputan koordinat, halaman ini dibuat agar pemegang wewenang dapat memeriksa data koordinat dengan teliti tanpa harus kembali ke halaman End-user. 


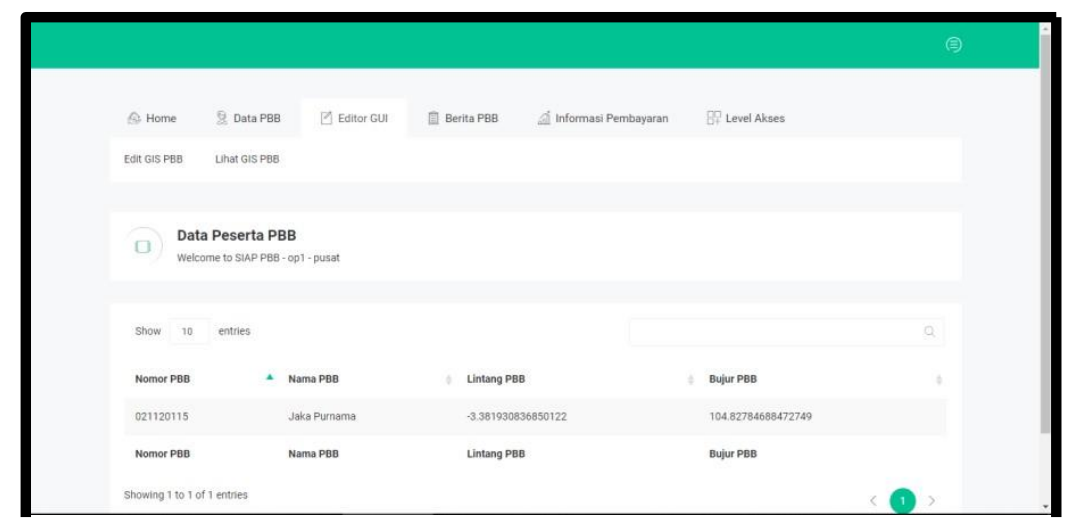

Gambar 6. Halaman Data Lokasi Koordinat Pembayar PBB

Halaman yang berisikan tentang koordinat dari pembayar pbb sehingga lokasi koordinat dapat dilihat jelas berdasarkan letak lintang dan bujur dalam sistem SIAP PBB.

\section{SIMPULAN}

Dari hasil yang sudah dilakukan pada penelitian ini mulai dari tahap awal sampai dengan proses pengujian, dapat disimpulkan bahwa dengan adanya Sistem Informasi Geografis sebagai media informasi pajak bumi dan bangunan (PBB) di kota kayu agung disimpulkan sebagai berikut :

1. Sistem informasi geografis telah dibuat berdasarkan atribut fungtionality, reliability, usability, efficiency pada ISO 9126, hasilnya dapat membantu pembayar pbb di kota kayu agung dalam mendapatkan informasi PBB secara cepat dan jelas sesuai dengan tempat atau lokasi PBB.

2. Sistem informasi geografis dapat membantu pembayar pbb dalam mendapatkan informasi PBB secara efisien karena Sistem Informasi Geografis ini menggantikan informasi yang harus didapatkan di tempat $\mathrm{rt}$ atau rw atau kelurahan atau kecamatan atau kantor pajak setempat sehingga sistem menjadi sarana informasi PBB yang dapat dilakukan dimanapun dan kapanpun oleh pembayar pajak.

Hasil dari pegujian Sistem Informasi Geografis di kota kayu agung dengan menggunakan white box dan black box berjalan dengan baik.

\section{DAFTAR RUJUKAN}

Adelina, R. (2013). "Analisis Efektifitas dan Kontribusi Penerimaan Pajak Bumi dan Bangunan (PBB) terhadap Pendapatan Daerah di Kabupaten Gresik." Jurnal Akuntansi Unesa 1(2).

Bentley, L. D., et al. (2000). Systems analysis and design methods, Irwin/McGraw Hill.

Kadir, A. (1999). Konsep \& Tuntunan Praktis Basis Data, Penerbit Andi.

Kadir, A. (2003). Pengenalan sistem informasi, Andi.

McConnell, S. (1996). Rapid development: taming wild software schedules, Pearson Education.

Pohan, H. I. and K. S. Bahri (1997). "Pengantar perancangan sistem." Jakarta: Erlangga.

Saputro, R. (2014). "Efektivitas Penerimaan Pajak Bumi dan Bangunan Perdesaan dan Perkotaan (Pbb P2) terhadap Peningkatan Penerimaan Pendapatan Asli Daerah (PAD)(Studi pada Dinas Pendapatan dan Pengelolaan Keuangan Kota Surabaya)." Jurnal Mahasiswa Perpajakan 2(1).

Sidharta, I. and M. Wati (2015). "Perancangan Dan Implementasi Sistem Informasi Urunan Desa (URDES) Berdasarkan Pada Pajak Bumi Dan Bangunan." Jurnal Computech \& Bisnis 9(2): 95107. 